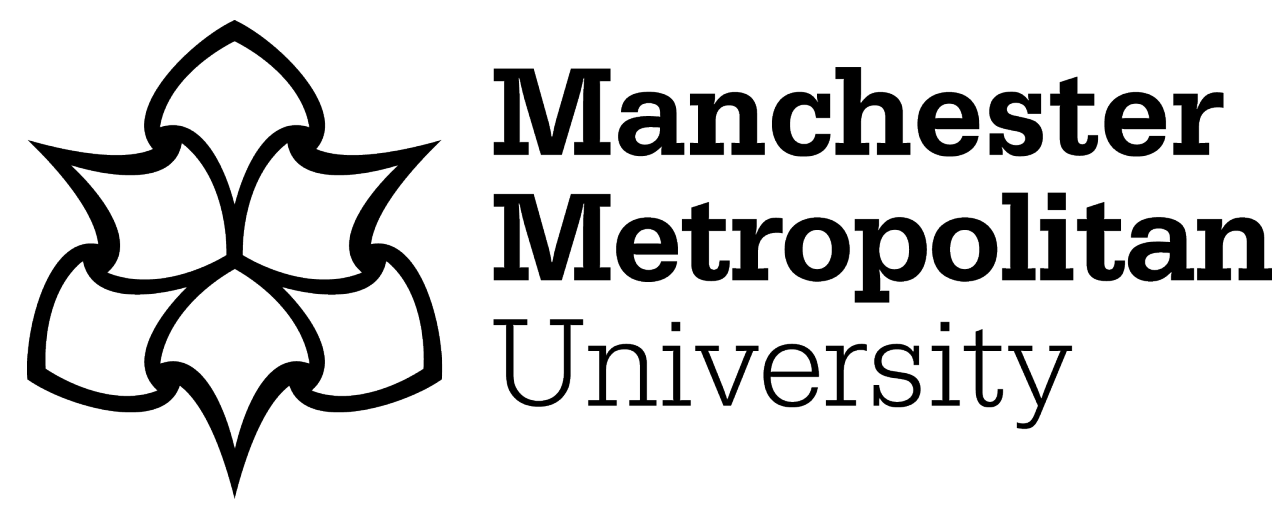

Giladi, P (2017) Idealism and the metaphysics of individuality. Philosophy and Social Criticism, 43 (2). pp. 208-229. ISSN 0191-4537

Downloaded from: https://e-space.mmu.ac.uk/621005/

Publisher: SAGE Publications

DOI: https://doi.org/10.1177/0191453715622522

Please cite the published version 


\section{Idealism and the Metaphysics of Individuality}

What is arguably the central criticism of Hegel's philosophical system by the Continental tradition, a criticism which represents a unifying thread in the diverse work of Schelling, Feuerbach, Kierkegaard, Nietzsche and Adorno, is that Hegel fails to adequately do justice to the notion of individuality.

My aim in this paper is to counter the claim that Hegel's idea of the concrete universal fails to properly explain the real uniqueness of individuals. In what follows, I argue that whilst the Continental critique (as it is particularly expressed by Adorno) is prima facie attractive, it is ultimately misguided. This is because the critics of Hegel fail to correctly understand (i) his principal argument in Sense-Certainty; (ii) crucial features of his logico-metaphysics; and (iii) his notion of wholeness. I contend that carefully explicating these important parts of the Hegelian system not only shows that Hegel's metaphysical commitments are not those which do not leave meaningful room for or make adequate sense of individuality, but that they also reveal a sophisticated treatment of the interdependency between the categories of individuality, particularity and universality in a way which conceives of individuality robustly.

Western metaphysics has traditionally offered two different approaches to solving the problem of individuals. The first of these is the bare particular theory of objects, according to which an individual object is identified with the underlying substratum in which its various properties inhere. ${ }^{1}$ However, while the bare particular theory appears to provide an answer explaining what constitutes the individuality of an object, namely that it is the thing which holds various properties together, the theory has often been rejected on the grounds that substrata are mysterious. ${ }^{2}$ Dissatisfaction with this way of solving the philosophical puzzle has led some philosophers to develop the bundle theory of objects, according to which an

\footnotetext{
${ }^{1}$ See the following from Locke: "If anyone should be asked, what is the subject wherein colour or weight inheres, he would have nothing to say, but the solid extended parts; and if he were demanded, what is it that solidity and extension inhere in, he would not be in a much better case than the Indian, who, saying that the world was supported by a great elephant, was asked what the elephant rested on; to which his answer was - a great tortoise: but being again pressed to know what gave support to the broad-backed tortoise, replied something, he knew not what". (EHU: 2, XXIII, §2, 268)

${ }^{2}$ Cf. EHU: 2, XXIII, §15, 305.
} 
individual object is identified as a collection of properties. ${ }^{3}$ However, while the bundle theory eliminates any kind of mysterious underlying subject of predication that confers haecceity on an individual object, it has problems of its own: if an individual is nothing more than a collection of various properties, it would follow - under Leibniz's Identity of Indiscernibles that objects are distinguished from one another if their properties are different. But, consider the following possibility: could there not be two objects with the same properties (size, shape, density, etc.), but those objects are distinct from each other? ${ }^{4}$ To deny this possibility would require the bundle theory to articulate an implausible version of the Identity of Indiscernibles, according to which no object could ever be numerically or qualitatively distinct from all other entities. Given the nature of this problem for the bundle theory of objects, their advocates often draw a distinction between intrinsic/pure properties and relational/impure properties, where the latter genus of property typically includes properties such as occupying a particular place in space-time. Though drawing this distinction between different genera of predicates weakens the Identity of Indiscernibles, the bundle theorist's counter risks trivialising Leibniz's principle, since the claim 'If two objects share the same pure and impure properties, then they are identical' is tautologous.

Both the bare particular theory and the bundle theory appear to leave us gripped by cognitive aporia: one tends to oscillate between the two with little hope of successfully navigating away from Scylla and Charybdis. However, as Robert Stern writes, "[a] natural way to respond to these difficulties is to look for a position that relies on more than just the properties of the individual ... to differentiate it, but in a way that does not go back to the earlier substratum model ..."5 One such position is the substance-kind theory. According to this way of way of characterising the distinctness of an individual object:

[k]inds are universals whose instantiations are numerically different; but the instantiations of a substance-kind just are the various substances which belong to or fall under it. Thus, there is no need either to deny what is obvious - that it is possible for different objects to be indiscernible with respect to their pure universals [which is the problem for the bundle theory] or to appeal to bare substrata in explaining how this is possible [as on the substratum theory]. Indiscernible substances agree in their substance-kinds; but for two or more objects to agree in a substance-kind is eo ipso for

\footnotetext{
${ }^{3}$ The bundle theory is notably advanced by Hume: "[N]one will assert, that substance is either a colour, or a sound, or a taste ... We have therefore no idea of substance, distinct from that of a collection of particular qualities, nor have we any other meaning when we talk of reason concerning it". (THN: 1, I, §VI, 16)

See the following from Dean Zimmerman, who defines the bundle theory in the following way: "All we observe or detect are the properties of things, and a particular substance is nothing more than a bundle of properties". (D. W. Zimmerman, 1997: 305)

${ }^{4}$ Cf. Black (1952).

${ }^{5}$ R. Stern, 2009: 348.
} 
them to be numerically different. Substance-kinds of and by themselves diversify their members, so that in being given substance-kinds we are thereby given universals that guarantee the diversification of the objects which exemplify them. ${ }^{6}$

Under the substance-kind theory, substance-kinds in and of themselves individuate objects: by virtue of being an instantiation of the kind 'man', Bill is distinct from Ted even if both Bill and Ted share the same universals in common, because qua man, Bill is a unique individual from all members of the same natural kind. Conceived in this way, one seems to have a way out of the oscillation between the bare particular theory and the bundle theory: an individual is not understood as an underlying bare substratum in which various properties inhere, nor is an individual simply constituted by the various properties it possesses; "rather, the properties inhere in the individual qua member of the kind, not as an indeterminate substratum", 7 to the extent that, as a man, Bill is dopy, tall, etc., where it is Bill's being a man that forms the various properties he possesses into a unique individual.

A key exponent of the substance-kind theory is Hegel, whose specific contribution to the debate is the distinction between the abstract and concrete universal. In Book III of the Logic, Hegel writes the following:

\begin{abstract}
As negativity in general or in accordance with the first, immediate negation, the universal contains determinateness generally as particularity; as the second negation, that is, as negation of the negation, it is absolute determinateness or individuality and concreteness. The universal is thus the totality of the Notion; it is concrete, and far from being empty, it has through its Notion a content, and a content in which it not only maintains itself but one which is its own and immanent in it. We can, indeed, abstract from the content: but in that case we do not obtain a universal of the Notion but only the abstract universal, which is an isolated, imperfect moment of the Notion and has no truth. (SL: 603-4)
\end{abstract}

The concrete universal is understood to involve a dialectical relationship between universality, individuality and particularity. Crucially, this is what distinguishes the concrete universal from the abstract universal; the abstract universal is not dialectically structured, hence why Hegel regards it as "isolated" and "imperfect". Its isolation and imperfection consist in how the abstract universal is the result of a poor way of relating the categories of universality, particularity, and individuality. Abstract universality is opposed to the particular

\footnotetext{
${ }^{6}$ M. J. Loux, 1978: 163-4. See also Lowe $(1989,1999)$.

${ }^{7}$ Stern, 2009: 349.
} 
and the individual. ${ }^{8}$ Concrete universality is not opposed to the particular and the individual. Furthermore, the concrete universal is the communion of universality, particularity and individuality. And, as such, is the proper conceptualisation of the relationship between these three categories. The significance of this can be found by discussing Hegel's analyses of certain judgements, which can shed light on what exactly a concrete universal is for Hegel.

(A) 'This rose is red': ${ }^{9}$ The property 'red' is here understood as something that belongs to the rose. The rose, of course, is not only red. For, the rose has a scent, form, texture, all of which are not contained in the property of being red. The rose being red does not entail that the only property of the rose is its being red, nor does it entail that the rose must have a particular scent, form, and texture based on its being red. Furthermore, 'is red' is not exclusively a property that one rose or all roses have. The universal is only accidentally related to the object. Therefore, with these kinds of universals, namely abstract universals, "there is a clear distinction we can draw between the universal and the individual that possess that property, and that universal and the other properties it possesses, so there is no dialectical unity here between these elements". ${ }^{10}$

(B) 'All men are mortal': Judgements of this form, according to Hegel, are a species of 'judgements of reflection', namely quantitative judgements. The property 'being a man' is an essential property of all individual members of the set of human beings. 'Being a man' is not an accidental property of all individual members of the set of human beings. 'Having auburn hair', for example, is a property which some but not all human beings possess. Furthermore, 'having hands' is a property which all human beings may possess, but that quality is not an essential property. 'Being mortal' is an essential property of all human beings - though, of course, not every mortal being is human. For Hegel, those quantitative judgements which are also necessary judgements - such as 'All men are mortal' - constitute the last form of the judgement of reflection, and as such, transition to the next major judgement form, the 'judgement

\footnotetext{
${ }^{8}$ Cf. SL: 602.

${ }^{9}$ This example is discussed by Hegel in the following passage from the Encyclopaedia Logic: "When we say: 'This rose is red', the copula 'is' implies that subject and predicate agree with one another. But of course, the rose, being something concrete, is not merely red; on the contrary, it also has a scent, a definite form, and all manner of other features, which are not contained within the predicate 'red'. On the other hand, the predicate, being something abstractly universal, does not belong merely to this subject. For there are other flowers, too, and other objects altogether that are also red". $(E L: \S 172,250)$

${ }^{10}$ Stern, 2007: 128 .
} 
of necessity'. In this instance now, the universal judgement 'All men are mortal' becomes equivalent to the judgement 'Man as such is mortal'. This kind of judgement is conceived of as a 'categorical judgement', the first type of judgement of necessity. ${ }^{11}$

(C) 'Caius is a man': 'Being human' is an essential property of Caius. "The single human is what he is in particular, only insofar as he is, first of all, human as such, and within the universal; and this universal is not just something over and above the other abstract qualities or mere determinations of reflection, but is rather what permeates and includes within itself everything particular”. $(E L: \S 175,253)$ Caius can only be a particular individual man if he is a man. And Caius cannot be an indeterminate man, he must be a determinate instantiation of man, "whose differences from other men nonetheless do not prevent him exemplifying the same universal 'man". ${ }^{12}$

All three judgements are used by Hegel to express a specific stage of the relationship between the categories of universality, particularity, and individuality. However, $(C)$ is the kind of judgement that arrives at the dialectical relationship between these three categories. The universal is now concrete, principally because it is what an individual is, in that an individual is an instantiation of that kind of universal: Caius is an instantiation of man. By exemplifying the property of being a man, even though Caius is distinct from other individual exemplifications of man, Caius is the individual that he is, while his being a man is also required for and compatible with the particular determinations that make him the specific man he is.

For Hegel, we can best make sense of the uniqueness of individuals by construing them in terms of the logico-metaphysical relations of concrete universality. This provides Hegel with a way of rejecting both the bare particular theory and the bundle theory: the problem with the bare particular theory is that a bare substratum with no properties of any sortal variety does not appear able to individuate objects; and the problem with the bundle theory is that it is exclusively limited to referencing abstract universals, so much so that because these properties are non-essential and accidental properties of an individual, we are naturally led to

\footnotetext{
${ }^{11}$ This idea is best expressed in the following passage from the Science of Logic: "[With the judgement of necessity] The subject has thus stripped off the form determination of the judgement of reflection which passed from this through some to allness; instead of all men we now have to say man... What belongs to all the individuals of a genus belongs to the genus by its nature, is an immediate consequence and the expression of what we have seen, that the subject, for example all men, strips off its form determination, and man is to take its place. This intrinsic and explicit connection constitutes the basis of a new judgement, the judgement of necessity". (SL: 649-50)

${ }^{12}$ Stern, 2007: 129.
} 
regard the individual as something which underlies predication and thereby adopt the bare particular conception of objects. In other words, what explains the cognitive disquietude of the phenomenological subject in 'Perception' - the antinomial conflict between the 'One' of the bare particular theory and the 'Also' of the bundle theory - is restricting the vocabulary of universality exclusively to "sensuous universality", ${ }^{13}$ abstract universality.

To his critics, however, Hegel's doctrine of the concrete universal represented an intellectual bete noire that needed to be refuted: for both the post-Kantian and post-Hegelian philosophical traditions, the relationship between individuality and universality was the most fundamental philosophic issue. This was because "on this question so much of our view of epistemology, ethics, political philosophy, aesthetics, and much else depends"; 14 as such, if one failed to adequately make sense of individuality to the extent of having individuality fade into indeterminacy by virtue of subsumption under a systematic whole, such conceptual impoverishment had disastrous consequences for socio-political and existential considerations. In what follows, I would like to explain why some important Continental philosophers were so troubled by Hegel's version of the substance-kind theory, and then explain how the epistemological objections by Feuerbach became the metaphysico-political criticisms by Adorno.

The first claim I would like to draw attention to is Hegel's idea in the Phenomenology of Spirit that conceptual articulation is a necessary condition for the possibility of language. Consider the following from Charles Taylor, who writes:

The new theory of language that arises at the end of the eighteenth century, most notably in the work of Herder and Humboldt, not only gives a new account of how language is essential to human thought, but also places the capacity to speak not simply in the individual but primarily in the speech community. This totally upsets the outlook of the mainstream epistemological tradition. Now arguments to this effect have formed part of the refutation of atomism that has proceeded through an overturning of standard modern epistemology.

Important examples of arguments of this kind are Hegel's in the first chapter of the Phenomenology of Spirit, against the position he defines as "sensible certainty," where he shows both the indispensability of language and its holistic character; and Wittgenstein's famous demonstrations of the uselessness of "ostensive definitions," where he makes plain the crucial role played by language in identifying the object and the impossibility of a purely private language. Both are, I believe, excellent examples of

\footnotetext{
${ }^{13}$ Cf. PS: 77.

${ }^{14}$ Stern, 2009: 351.
} 
arguments that explore the conditions of intentionality and show their conclusions to be inescapable. $^{15}$

According to Taylor, an important feature of Hegel's discussion of Sense-Certainty is Hegel's aim to show how the necessary conditions for the possibility of language render the position of Sense-Certainty incoherent. For, Hegel's target in the opening chapter of the Phenomenology is someone who thinks that reference is possible by virtue of providing ostensive definitions. ${ }^{16}$ In other words, according to the Sense-Certainty theorist, I am able to pick out individual objects and label such objects as those objects simply by pointing to those and only using ostensive indexicals. As Robert Pippin writes, “... the goal [of Hegel's argument] is obviously to demonstrate that even the simplest form of demonstrative reference would not be possible without some describing capacity, a capacity that requires descriptive terms or predicates ... not merely deictic expressions and atomic objects". ${ }^{17}$ To see how this works, let us briefly consider Hegel's argument: according to the sense-certainty theorist, I can pick out and refer to an individual object by pointing to it and dubbing it the here-andnow. For sense-certainty, here-and-now is meant to capture a unique feature of an object and thus enable me to refer to that individual object. However, Hegel proceeds to argue that being here-and-now is far from unique to the object, as different times and places can come to be here-and-now, and thus so can different things. Sense-certainty, therefore, has failed to properly refer to this particular object by virtue of picking out its singular individuality, because all that sense-certainty has been able to do is to pick out a property that can belong to many individuals, a property which is universal. ${ }^{18}$ Not only that, the ultimate problem with sense-certainty's commitment to referring to individual objects without reference to concepts - what Hegel calls apprehension - is that the non-conceptual 'describing' capacities fail to refer simpliciter, because what we discover in the dialectic of sense-certainty is that concepts

\footnotetext{
${ }^{15}$ C. Taylor, 1987: 13.

${ }^{16}$ For further on Hegel's transcendental concerns in Sense-Certainty, see Taylor (1972), Dulckeit (1986), Pippin (1989), Pinkard (1994), Stern (2012), and Houlgate (forthcoming).

${ }^{17}$ R. B. Pippin, 1989: 117.

18 “....in this simplicity [Now] is indifferent to what happens in it; just as little as Night and Day are its being, just as much also is it Day and Night; it is not in the least affected by this its other-being. A simple thing of this kind which is through negation, which is neither This nor That, a not-This, and is with equal indifference This as well as That - such a thing we call a universal. So it is in fact the universal that is the true [content] of sensecertainty... The same will be the case with the other form of 'This', with 'Here'. 'Here' is e.g., the tree. If I turn round, this truth has vanished and is converted into its opposite: 'No tree is here, but a house instead'. 'Here' itself does not vanish; on the contrary, it abides constant in the vanishing of the house, the tree, etc., and is indifferently house or tree. Again, therefore, the 'This' shows itself to be a mediated simplicity, or a universality... [S]ense-certainty has demonstrated in its own self that the truth of its object is the universal." (PS: 60-61)
} 
and a holistic logico-linguistic framework ${ }^{19}$ are necessary conditions for the possibility of reference. Sense-certainty, therefore, can be refuted on grounds that it violates the necessary conditions for the possibility of language. As Hegel writes:

It is a universal too that we utter what the sensuous content is. What we say is: 'This', i.e. the universal This; or, 'it is', i.e. Being in general. Of course, we do not envisage the universal This or Being in general, but we utter the universal; in other words, we do not strictly say what is this sense-certainty we mean to say. But language, as we see, is the most truthful; in it, we ourselves directly refute what we mean to say, and since the universal is the true content of sense-certainty and language expresses this true content alone, it is just not possible for us ever to say, or express in words, a sensuous being that we mean ... (PS: 85-7)

According to Feuerbach, the principal failing of Hegel's argument against SenseCertainty is (i) that Hegel's critique of Sense-Certainty does not proceed immanently; and (ii) that the ineffability of non-conceptual articulation of experiential content shows the limitation of language itself rather than the alleged emptiness of apprehension:

But is this a dialectical refutation of the reality of sensuous consciousness? Is it thereby proved that the general is the real? It may well be for someone who is certain in advance that the general is the real, but not for sensuous consciousness or for those who occupy its standpoint and will have to be convinced first of the unreality of sensuous being and the reality of thought ... Here, language is irrelevant. The reality of sensuous and particular being is a truth that carries the seal of our blood ... Enough of words: come down to real things! Show me what you are talking about! To sensuous consciousness, it is precisely language that is unreal, nothing. How can it regard itself, therefore, as refuted if it is pointed out that a particular entity cannot be expressed in language? Sensuous consciousness sees precisely in this a refutation of language and not a refutation of sensuous certainty. (FB: 77-9)

Though Feuerbach contends that Hegel's refutation of Sense-Certainty does not proceed immanently but rather presuppitionally, I do not think this part of his objection to Hegel works, because a careful reading of Hegel's text clearly shows how conceptual articulation being necessary for reference is a revelation for consciousness when adopting the epistemic framework of Sense-Certainty. If one looks at Hegel's argument in 'Sense-Certainty', one will immediately notice that Hegel is making transcendental claims about our cognition. However, these claims about the necessary conditions for the possibility of demonstrative reference and determinate cognition of concrete particulars are not presuppositions made by Hegel. Rather, these transcendental insights are propositions that the phenomenological

19 By this, I mean being endowed with capacities that enable us to draw distinctions and similarities determinate negations - and relations between things - formal and informal inferences. 
subject discovers during its dialectical journey through sense-certainty. They are cognitive achievements, as opposed to dogmatic assumptions. ${ }^{20}$ This is why sense-certainty transforms into perception $-^{21}$ given how sense-certainty's criterion for knowledge is incoherent on its own terms when tested against experience, a new form of consciousness is adopted in an effort to better make sense of the kind of experience sense-certainty claimed it could account for but in fact failed to satisfactorily explain. ${ }^{22}$

While this part of Feuerbach's critique of Hegel can be dealt with fairly swiftly, his claim that our inability to refer to bare particulars and discursively grasp the haecceity of an individual object shows the limitations of what language can do poses more philosophical difficulty: as I understand Feuerbach's position, his worry about language centres on how key features of propositional articulation, namely concepts, are inherently general; and because these features of language are inherently general, it is left unclear how exactly general terms fully capture the specificity of the referred individual object. To put this another way, the practice of conceptualising objects only seems to establish how we can judge things to bear resemblances with one another and then enable us to make further general judgements about $x$-things are thus-and-so. Such a practice, while obviously helpful in some respects, seems to fail to do justice to a factive element of experience: the predicates involved in our judgements about states of affair are presented as phenomenologically distinct Kantian intuitions or Russellian sense-data.

However, the problem with Feuerbach's concern about language being too general to pick out specificity and individuate objects is that such a problem only arises from the perspective of ordinary consciousness, where it is precisely the binary logical structure of ordinary consciousness that comes under Hegelian scrutiny: qua philosophical consciousness, one realises that in saying 'The rose is red', the semantic content cannot be given independently of an account of the kinds of inferential commitments one must make in the activity of assertion: to be able to pick out this particular rose as being this particular colour, one must know that the rose cannot be yellow or blue, etc. Not only that, for Hegel, what makes 'The rose is red' a judgement rather than just a saying, is the role determinate negation plays in

\footnotetext{
${ }^{20} \mathrm{Cf}$. "It is clear that the dialectic of sense-certainty is nothing else but the simple history of its movement or of its experience ..." (PS: 64)

${ }^{21} \mathrm{Cf}$. "... by pointing out this bit of paper, experience teaches me what the truth of sense-certainty in fact is: I point it out as a 'Here', which is a Here of other Heres, or is in its own self a 'simple togetherness of many Heres'; i.e. it is a universal. I take it up then as it is in truth, and instead of knowing something immediate I take the truth of it, or perceive it". (PS: 66)

${ }^{22} \mathrm{Cf}$. "The wealth of sense-knowledge belongs to perception, not to immediate certainty, for which it was only the source of instances; for only perception contains negation, that is difference or manifoldness, within its own essence". (PS: 67)
} 
providing the conditions under which picking out an individual object is mediated through contrasting it with other possibilities of predication and other objects. ${ }^{23}$ Why, then, bare particularity and certain characterisations of an individual object's haecceity are dismissed by Hegel is precisely because neither bare particularity nor haecceity provide the conditions for successfully picking out an individual object, since apprehension is entirely indeterminate.

Thus far, I have focused on Feuerbach's logico-epistemological concerns with Hegel's position on the relationship between universality and individuality. I have argued that there are good reasons to suppose that Feuerbach's critique of Hegel's reflections on SenseCertainty do not hold much water. However, a more sophisticated and powerful criticism of Hegel's solution to the problem of individuality comes from Adorno, whom I take as radicalising the Feuerbachian objection to Hegel. ${ }^{24}$

According to Adorno:

\begin{abstract}
It might be said with some exaggeration that matter is the principium individuationis in Aristotle, and not, as we are inclined to think, form, which is that which determines a particular thing as particular. For him, however, individuation itself is founded precisely on this particularisation - the lack of identity, or full identity, of an existent thing with its form. Individuation thus becomes something negative in Aristotle. And that, too, is a basic thesis of western metaphysics, as it reappears in Kant, where cognition is equated with the determining of an object in its generality and necessity, and as you find it working to its extreme in Hegel, where only the universal manifesting itself through individuation is the substantial - whereas anything which lies outside the identification with the universal principle is regarded as absolutely insignificant, ephemeral and unimportant. (Metaphysics: 79)
\end{abstract}

For Adorno, what is symptomatic of western metaphysics is the apparent long-standing philosophical tradition of prioritising universality over individuality, a tradition which begins with Plato and is fully actualised in Hegelian thought: prioritising universality over individuality is evidenced in claiming that while individual objects do have distinctive features, their qualitative distinctness is metaphysically grounded in underlying sameness: Bill and Ted are individual entities and they have different properties, but they only have those specific properties by virtue of being particular instantiations of the same substance-

\footnotetext{
${ }^{23}$ Hegel makes this especially clear in 'Perception', where he writes the following: “... if the many determinate properties were strictly indifferent to one another, if they were simply and solely self-related, they would not be determinate; for they are only determinate insofar as they differentiate themselves from one another, and relate themselves to others as to their opposites". (PS: 69)

${ }^{24}$ One could argue that the Feuerbachian objection to Hegel is in fact more of a Schelling-inspired criticism of Hegel. As Schelling wrote: "We live in this determinate world, not in an abstract or universal world that we so much enjoy deluding ourselves by holding fast to the most universal properties of things, without penetrating to their actual relationships". (SW 14:332)
} 
kind. In this sense, universality is metaphysically prior to individuality, as there can be no individuality without universality. ${ }^{25}$ However, such metaphysical prioritisation is regarded by Adorno as potentially harmful: the practice of conceptualisation in terms of bringing things under general descriptions and rule-following is an intrinsically violent and authoritarian practice, ${ }^{26}$ because "particularity and non-identity are sacrificed to the system's demand for unity". ${ }^{27}$ Since Begriffe function to seize the things they are directed at, ${ }^{28}$ the activity of making sense of things through the application of rule-conforming concepts does not respect the integrity of Being; rather, if anything, this particular genus of discursivity is effectively some kind of viol cognitif, where reality is forced to conform to concepts. Such violence seems to translate into a form of eerie conservatism, because subsuming things under general terms leads to assimilating "all individuals into a general type, and thereby exclude or devalue their difference or singularity". ${ }^{29}$ As Adorno writes:

unity gets worse as its seizure of plurality becomes more thorough. It has its praise bestowed on it by the victor, and even a spiritual victor will not do without his triumphal parade, without the ostentatious pretence that what is incessantly inflicted upon the many is the meaning of the world ... Thus established, the logical primacy of the universal provides a fundament for the social and political primacy that Hegel is opting for. (ND: 328)

Prima facie, there seems to be a plethora of passages which appear to support his interpretation of Hegel as prioritising universality over individuality and even regarding individual objects to be ontologically deficient and axiologically insignificant. ${ }^{30}$ Consider, for example, the following passages from Hegel's writings: ${ }^{31}$

\footnotetext{
${ }^{25}$ See also the following passage from Negative Dialectics: "Hegel concludes in an ever-recurring mode, the particular is nothing. The modern history of the human spirit - and not that alone - has been an apologetic labour of Sisyphus: thinking away the negative side of the universal". (ND:327)

${ }^{26} \mathrm{Cf}$. "What tolerates nothing that is not like itself thwarts the reconcilement for which it mistakes itself. The violence of equality-mongering reproduces the contradiction it eliminates". (ND: 142-3)

27

${ }^{28}$ The German term for 'concept', Begriff, comes from the verb Begreifen, which in turn is derived from Greifen. 'Greifen' is often translated as meaning 'to grab/to grip/ to seize/ to snatch/to capture/ to strike/to take hold/to bite'.

${ }^{29}$ Stern, 2009: 367.

${ }^{30}$ To use Adorno's expression, "the supremacy of the universal". (ND: 334)

${ }^{31}$ See also the following passages from Hegel's lectures on the philosophy of world history: "Reason cannot stop to consider the injuries sustained by singular individuals, for particular ends are submerged in the universal end" (LPWH: 43); "Individuals fade into insignificance beside the universal substance" (LPWH: 52); "The worth of individuals is measured by the extent to which they reflect and represent the national spirit, and have adopted a particular station within the affairs of the state as a whole" (LPWH: 80).
} 
Nature offers us an infinite mass of singular shapes and appearances. We feel the need to bring unity to this manifold; therefore, we compare them and seek to [re]cognize what is universal in each of them. Individuals are born and pass away; in them their kind is what abides, what recurs in all of them; and it is only present for us when we think about them ... in thinking about things, we always seek what is fixed, persisting, and inwardly determined, and what governs the particular. $(E L: \S 21 Z, 53)$

The proposition that the finite is ideal constitutes idealism. The idealism of philosophy consists in nothing else than in recognizing that the finite has no veritable being. Every philosophy is essentially an idealism, or at least has idealism for its principle, and the question then is how far this principle is actually carried out. This is as true of philosophy as of religion; for religion equally does not recognize finitude as a veritable being, as something ultimate and absolute or as something underived, uncreated, eternal. Consequently the opposition of idealistic and realistic philosophy has no significance. A philosophy which ascribed veritable, ultimate, absolute being to finite existences as such, would not deserve the name of philosophy ... (SL: 154-5)

According to a natural reading of these passages, ordinary consciousness, conceived as a form of understanding the world by appeal to what is immediately given to us in perception and scientific verification, treats concrete particulars as 'ultimate' or 'absolute' or 'selfexplanatory', because the epistemic framework of ordinary consciousness refuses to go beyond what is immediately given to us in perception and scientific verification. Hegel's point here is that if we are to genuinely think philosophically about the world of experience, we must be prepared to reject the metaphysical supposition that concrete particulars are the only things which exist and the epistemic supposition that explanation is restricted to the standards of ordinary consciousness: the intellectual demand on rational agents, then, is one which aims to maintain the dependence of concrete particulars on more 'real' entities, such as universals, in order to do justice to the standards of philosophical consciousness. Philosophical consciousness, whose criteria of explanans is the standpoint of reason rather than the standpoint of the understanding, is a "form of holistic explanation, which shows how all finite things are parts of a wider whole". ${ }^{32}$ From this perspective, the aim of enquiry is not to focus on individuality, because our principal philosophic aim is to always seek what is fixed, persisting, and what governs the particular. ${ }^{33}$ Moreover, given this framework, what Hegel argues in these passages and throughout his entire work is that the reality an individual entity has is determined by its relation to a substance-kind: Bill is an instance of man; Ted is another instance of man. In other words, there is no fundamental difference between things. ${ }^{34}$

\footnotetext{
${ }^{32}$ F. C. Beiser, 2005: 165.

${ }^{33}$ The use of the term 'govern' is important here, as that seems to justify Adorno's worry about the post-Kantian understanding of conceptualisation in some sense.

${ }^{34}$ I think it is worth noting that Adorno's charge that Hegelian idealism fails to make room for a robust notion of individuality bears a very close resemblance to Ranke's historicist critique of Hegel in his 1831 lectures on
} 
Ironically, then, it seems Adorno can be regarded as turning Hegelian metaphysics on its head. For, in an effort to distinguish his objective idealism from Schelling's objective idealism, Hegel (in)famously claimed that Schellingian monism left with a view of Being in terms of "the night in which all cows are black" (PS: 9). In other words, Schelling allegedly fails to make any room for individuals and is committed to an absurd conception of reality as being essentially undifferentiated and undifferentiating. However, from the Adornian perspective we have discussed so far, it would seem that Hegel is in fact guilty of the very thing he so publicly accused Schelling of doing. The question, now, is whether Adorno is correct.

III

Although there appear to be good reasons supporting Adorno's critique of Hegel, I think his criticism is ultimately misguided. Firstly, whilst it is true that Hegel accounts for a dialectical relationship between universality, particularity, and individuality, it does not thereby follow that Hegel is committed to the kind of absolute monism he attributed to Schelling: in the opening stages of the Science of Logic, Hegel makes use of Spinoza's 'All Determination is Negation' in an effort to reject precisely what Adorno accuses him of doing: ${ }^{35}$ the negation that accompanies determination is a necessary condition for the possibility of being in any genuine sense. In other words, Hegel claims that if anything is to be, then it must have determination and so negation. His argument can be understood as follows: for anything to be more than just a completely formal and abstract pure being, ${ }^{36}$ which for Hegel is the same as nothingness, ${ }^{37}$ there must be some kind of determination. Such determination must involve some negation. ${ }^{38}$ As Stern writes, "the principle thus plays an important role within Hegel's

universal history: according to Ranke, Hegel sees the individual only as the instance of a universal, whereas historians aim to establish what is especially unique about the individual, rather than know the general laws that govern a thing. Contra speculative idealism, historicism understands the infinite in relation to the finite, as opposed to understanding the finite in relation the infinite. See Beiser (2014) for further on Ranke and historicism.

${ }^{35} \mathrm{Cf} . \mathrm{SL}: 113,536$; and $E L: \S 87 \mathrm{Z}, \S 91 \mathrm{Z}$.

${ }^{36}$ In the words of Pringle-Pattison, Hegel is staunchly opposed to a view of Being in which all determinations are "devoured, like clouds before the sun, in the white light of the unica substantia" (MPC: 173).

${ }^{37}$ Cf. SL: 82 .

${ }^{38}$ See the following from Stephen Houlgate:

"For Parmenides...[t]rue being is thus purely affirmative with no trace of negation or indeed change in it; it is thus 'uncreated and imperishable'. This conception of being as purely affirmative continues to cast its shadow over subsequent philosophy right up to the modern period. It is to be seen, for example, in Spinoza's assertion that 'the definition of any thing affirms, and does not deny, the thing's essence,'... [But] According to Hegel's account, the category of being proves to harbor within itself the moment of negation in several forms: the concept of reality entails negation in the form of determinacy and difference; being something entails negation 
ontological position, where it is crucial to his case against Parmenidean monism, which treats reality as a 'one', lacking in any element of difference; rather, Hegel argues, reality must incorporate some element of differentiation, of distinctions within being, where without these 'negations' it would not comprise determinate being, but would be no more than the nothingness of pure being". ${ }^{39}$ One can, therefore, see the opening stages of the Logic as providing the speculative metaphysical grounding of this famous part of the Phenomenology:

\begin{abstract}
Nowadays we see all value ascribed to the universal Idea in this non-actual form, and the undoing of all distinct, determinate entities (or rather the hurling of them all into the abyss of vacuity without further development or any justification) is allowed to pass muster as the speculative mode of treatment. Dealing with something from the perspective of the Absolute consists merely in declaring that, although one has been speaking of it just now as something definite, yet in the Absolute, the $\mathrm{A}=\mathrm{A}$, there is nothing of the kind, for all there is one. To pit this single insight, that in the Absolute everything is the same, against the full body of articulated cognition, which at least seeks and demands such fulfilment, to palm off its Absolute as the night in which, as the saying goes, all cows are black - this is cognition naively reduced to vacuity. (PS: 9)
\end{abstract}

However, in response, Adorno can claim that the notion of individuality Hegel is committed to is ultimately metaphysically insipid, because his principal philosophical concern seems to be establishing unity. As Hegel writes on the subject of the infinite/finite relation:

[It is said that] the infinite, one the one side, exists by itself, and that the finite which has gone forth from it into a separate existence ...; but it should rather be said that this separation is incomprehensible ... But equally it must be said that they are comprehensible, to grasp them even as they are in ordinary conception, to see that in the one there lies the determination of the other ... is to see the simple insight into their inseparability ... This unity of the finite and infinite and the distinction between them are just as inseparable as are finitude and infinity. (SL: 153-4)

From the above passage, we can construct the following argument:

(1) If the finite is separate from the infinite, then there is something outside of the infinite.

(2) There is nothing outside of the infinite.

(3) Therefore, the finite is not separate from the infinite.

in the form of otherness and finitude; and infinite being also contains negation insofar as it lives in and through self-negating, finite beings". (S. Houlgate, 2006: 43-4)

${ }^{39}$ Stern, forthcoming: 2 - pages are referenced as they appear in the manuscript. 
Hegel is concerned with dismissing the claims of pre-Kantian rationalists as metaphysical conjecture, since if the infinite were understood in opposition to the finite, then the infinite would be finite itself, because it would be limited by the finite. "There would then be per impossibile a greater reality than the infinite. Hence, the true infinite must therefore include the finite" ${ }^{40}$ However, this conclusion - that the finite is not separate from the infinite - does not obviously mean that the finite is subsumed into a unity in such a way that eliminates the individuality and difference of individual entities. As Hegel writes in the Difference essay:

To cancel established oppositions is the sole interest of reason. But this interest does not mean that it is opposed to opposition and limitation in general; for necessary opposition is one factor of life, which forms itself by eternally opposing itself, and in the highest liveliness totality is possible only through restoration from the deepest fission. ( $D F \& S$ : 91)

This is perhaps the crucial issue which Adorno's critique of Hegel appears to either neglect or misunderstand: though Hegel's idiosyncratic language does not prima facie help his case, his concern with cancelling oppositions is one which is dialectical. The notion of wholeness that Hegel espouses is not one which aims to collapse individuals into universals or translate talk about individuals into talk about general kinds, but rather aims to undermine a non-dialectical approach to dualities such as universality and individuality:

\begin{abstract}
When people speak of the Concept, they ordinarily have only abstract universality in mind, and consequently the Concept is usually also defined as a general notion. We speak in this way of the 'concept' of colour, or of a plant, or of an animal, and so on; and these concepts are supposed to arise by omitting the particularities through which the various colours, plants, animals, etc., are distinguished from one another, and holding fast to what they have in common. This is the way in which the understanding apprehends the Concept, and the feeling that such concepts are hollow and empty, that they are mere schemata and shadows, is justified. What is universal about the Concept is indeed not just something common against which the particular stands on its own; instead the universal is what particularises (specifies) itself, remaining at home with itself in its other, with unclouded clarity. (EL: §164Z, 240)
\end{abstract}

Understood in this way, Hegel could claim that Adorno is guilty of approaching the subject of universality and individuality in exactly the sort of way Hegel rejects, namely from the perspective of thinking either universality is prior to individuality or individuality is prior to universality, rather than from the perspective of thinking of universality and individuality as

\footnotetext{
${ }^{40}$ Beiser, 2005: 142.
} 
interdependent. Such a philosophical perspective not only begs the question against Hegel, but also gives rise to anxieties concerning the alleged eerie conservatism of Hegelian thought: in the case of the dialectical interplay of universality, particularity, and individuality, to acknowledge our dependence on the concrete universal does not seem to represent a sort of "blithely decreed disappearances of individualities", 41 surrender of subjectivity or an ontological devaluation of individuality; individuals are still rather ontologically robust, even if they are not radically different as Adorno seems to want individuals to be. Far from being serfs determining our identity by our position in a feudal ontological hierarchy, and far from being "fungible and replaceable", “... human beings are not cogs in a vast cosmic mechanism, but rather are free, creative agents capable of transforming the world through the active realisation of intelligent ideals". ${ }^{43}$ One useful way of explicating how Hegel's dialectical understanding of individuality is supposed to work can be found in his Lectures on the History of Philosophy, where he contrasts his approach to that of Spinoza's:

\begin{abstract}
This idea of Spinoza's must be acknowledged to be true and well-grounded. There is an absolute substance, and it is what is true. But it is not yet the whole truth, for substance must also be thought of as inwardly active and alive, and in that way must determine itself as spirit. Spinoza's substance is the universal, and consequently the abstract, determination... If thinking stops with this substance, there is then no development, no life, no spirituality or activity. So we can say that with Spinozism everything goes into the abyss but nothing emerges from it. (LHP: 122)
\end{abstract}

Though Hegel acknowledges a metaphysical debt to Spinoza, namely that there is an absolute substance on which we are all ontologically dependent, he makes it clear that he differs from Spinoza on the basis that Hegelian metaphysics makes substantial room for spirit: ${ }^{44}$ Geist, for Hegel, is understood as necessarily involving an intersubjective play of intentionality, where mutual recognition between individual agents results in the notion of a community. ${ }^{45}$ Crucially, though, such a community is not one which deprives the individual of a meaningful concept of autonomy, because recognitive relationships - for all of their emphasis on the unity of a given community - necessarily involve a commitment to difference.

\footnotetext{
41 ND: 325.

${ }^{42}$ Ibid., p. 362.

${ }^{43}$ P. Forster, 2011: 245.

${ }^{44}$ For defences of Spinoza against Hegel's criticisms, see Melamed (2010, 2012), and Newlands (2011).

${ }^{45}$ See the following passage: "What still lies ahead for consciousness is the experience of what Spirit is - this absolute substance which is the unity of the different independent self-consciousnesses which, in their opposition, enjoy perfect freedom and independence: ' $I$ ' that is 'We' and 'We' that is ' $I$ '. It is in selfconsciousness, in the Notion of Spirit, that consciousness first finds its turning-point, where it leaves behind it the colourful show of the sensuous here-and-now and the nightlike void of the supersensible beyond, and steps out into the spiritual daylight of the present". (PS: 110-1)
} 
Similarly, Hegel's position on love seems to be arguably the best example of genuine intersubjectivity: love, conceived of as a unity between two individuals, can only exist through difference, since love requires "the most genuinely other" ${ }^{46}$ So, rather than view Hegel as advocating a monochromatic and totalitarianism monism, as someone who "has no interest in there being individuality at all", ${ }^{47}$ one ought to regard him as advocating a polychromatic and republican pluralism. As Charlotte Baumann rightly claims, "[i]t is precisely Hegel's intention to develop a conception of a whole which constitutes different entities and allows for their free existence within it, rather than destroying them". ${ }^{48}$ In order, though, to see how exactly Hegel advocates this polychromatic and republican pluralism, one needs to explicate the connection between Hegel's metaphysics of individuality and his conception of the place of the individual in the state.

I earlier argued that Hegel's commitment to wholeness is one which is meant to avoid the dangers of Eleatic monism. For Hegel, the problem with such monism is that it fails to make any room for individuals and is committed to an absurd conception of reality as being essentially undifferentiated and undifferentiating. On the socio-political front, such ontological totalitarianism would inevitably be the theoretical concomitant of a rather eerie form of conservatism. The challenge, therefore, for Hegel's social theory is to articulate a notion of wholeness which does not bring about or facilitate social totalitarianism.

According to Hegel, the state is conceived of as a whole, one whose structure is constituted by mediated unity: in contrast to Attic ethical life, the individual now no longer defines themselves as purely a functioning part of the community; and in contrast to modern ethical life, typified by Abstract Right (personal freedom) and Morality (moral freedom), the individual does not regard their subjectivity to define themselves as fundamentally separate from the societal domain. The transition from immediate unity through difference to mediated unity, the social freedom of Sittlichkeit, ${ }^{49}$ is one which is meant to represent how the individual regards the state as a partner for fostering the development of their rational capacities in an effort to achieve self-realisation. In other words, from the perspective of mediated unity, the individual is not conceived of simply as an anonymous cog in the workings of a complex social machine, and nor is the individual conceived of as antagonistic to the state. Rather, the individual is conceived of as a bona fide self-determining and

\footnotetext{
${ }^{46}$ M. Westphal, 1993: 35.

${ }^{47}$ ND: 342.

${ }^{48}$ C. Baumann, 2011: 90.

49 See $P R$ : $\S \S 157-8,181$. In his social philosophy, Hegel uses 'immediate unity', 'difference', and 'mediated unity' as equivalent terms for 'universality', 'particularity', and 'individuality'.
} 
rationally self-reflexive agent who requires assistance from the state in an effort to realise their own autonomy. As Fred Neuhouser writes, "what makes social institutions good, on Hegel's view, is that they play an indispensable role in "realising" freedom". 50

One especially helpful way of understanding the nuances of Hegel's position here can be provided by Dewey: the classical pragmatist approach to the dualism of state and the individual is one which finds the framework that gives rise to oscillating between authoritarianism and anarchism or conservatism and liberalism to be problematic. Dewey is critical of classical liberalism for conceiving of the individual as prior to society and that social institutions must therefore be organised in such a way so as to serve the interests of pre-societal individuals. In the same way that the early modern tradition conceived of the phenomenological relation between mind and world as one of fundamental separation, Dewey claims that classical liberalism is a practical exemplification of "the most pervasive fallacy of philosophical thinking", ${ }^{51}$ namely dividing up and separating phenomena into strict distinctions from one another. Contra this picture of the individual and its corresponding conception of freedom, Dewey aims to eliminate the philosophical pathology of a radical separation of the individual and social institutions by advocating a nuanced political holism: ${ }^{52}$

Liberalism knows that an individual is nothing fixed, given ready-made. It is something achieved, and achieved not in isolation but with the aid and support of conditions, cultural and physical: - including in "cultural", economic, legal and political institutions as well as science and art. ( $L W 11: 291)$

As with the dissolution of the mind/world dualism, the individual and state are no longer conceived of as fundamentally separate from another, pace the classical liberal picture according to which one's freedom is understood exclusively negatively as autonomy from any external constraint on one's ability to pursue such-and-such. Rather, according to Dewey's political holism, we understand freedom in terms of a positive capacity to realise oneself. Crucially, moreover, such individual self-realisation can only be achieved by conceiving of individuality as necessarily embedded in a reflective and social environment. One can, therefore, regard Dewey as Hegel's social heir, to the extent that like Hegel, Dewey advocates that "having identity-constituting attachments to one's community is made

\footnotetext{
${ }^{50}$ F. Neuhouser, 2008: 204. For further on this subject, see Patten (1999) and Neuhouser (2000).

${ }^{51}$ J. Dewey, 1981-1990 5: 5.

${ }^{52}$ To put this more simply, where the previous philosophical traditions had fundamentally separated mind and world and individuality and the state, both Hegel and the classical pragmatists hoped to make mind and world and individuality and state interdependent with one another.
} 
compatible with conceiving of oneself as an individual - that is, as a person with rights and interests separate from those of the community, and as a moral subject who is both able and entitled pass judgement on the goodness of social practices. [And that] the institutions within which modern individuals achieve their particular identities also promote personal and moral freedom by bringing about the social conditions without which those freedoms could not be realised". ${ }^{53}$ So, central to both Hegel's and Dewey's political holism is a clear commitment to bona fide individuals whose subjectivities are not lost or denigrated in a social whole. ${ }^{54}$

However, in response to my articulation of Hegel's position, Adorno could claim my way of interpreting Hegel appears to paper over dark undertones necessarily embedded in the language of community, unity, and wholeness. ${ }^{55}$

Hegel's transposition of the particular into particularity follows the practice of a society that tolerates the particular only as a category, a form of the supremacy of the universal. $(N D: 334)$

As James Gordon Finlayson writes, “Adorno sees in Hegel's system and the violence it perpetrates on particulars (in spite of its aspirations to the contrary) an analogue to the presently existing social system and the real violence it perpetrates on individuals. Hegel's system, he claims, provides a model for understanding twentieth century totalitarian society avant la lettre ... It is totalitarian and is complicit with actual totalitarianism". ${ }^{56}$ The explanation for why Adorno insists Hegel's system is totalitarian and perverts individuality is that Hegelian social theory is not opposed to capitalism in toto: according to Adorno, the market economic system is typified by the "levelling principle of exchange", 57 namely the idea that "individual products and human beings count on the market only as equal, atomistic examples of universal concepts like value and labour power". ${ }^{58}$ Given that individuals are defined as units of capitalist practices rather than as autonomous agents with specific wants and needs, one cannot regard them as genuinely free in the market system. And since Hegel appears rather proto-Honnethian in terms of suggesting capitalism has been a force for

\footnotetext{
${ }^{53}$ Neuhouser, 2008: 209.

${ }^{54}$ For further on this subject, see Hardimon (1994).

55 "... [I]nterpreters of Hegel often construed his talk of "the free whole" as evidence of the totalitarian character of his social philosophy, which was thought to subordinate the interest of individuals to some mysterious "freedom of the whole"'. (Neuhouser, 2008: 211)

${ }^{56}$ J. G. Finlayson, 2014: 1160. Given this, it would appear one has reason to give credence to Adorno's hermeneutical principle that "what these works say, is not what their words say" (AT: 184).

${ }^{57} N D: 179$.

${ }^{58}$ Baumann, 2011: 77.
} 
autonomy when properly institutionalised, rather than claim that regardless of any regulatory proviso capitalism is a force for un-freedom, there seems to be reason to think Hegelian social theory is hardly saturated with emancipatory intent.

Though one can certainly see the appeal of Adorno's rebuttal here, I think there is considerable risk for the critical theoretic remark being unreasonable: my concern is that any attempt at claiming Hegel's position does not result in both ontological and social totalitarianism, no matter how well argued for, will always be viewed by the critical theorist as in collusion with oppressive ideology. To put this another way, a defender of Hegel may offer the most careful and well-supported reading of concrete universality/mediated unity as not supporting either directly or indirectly ideological oppression, but the Adornian reply will claim that, regardless of the intentions or competency of the arguments offered, the defender of Hegel will be deluding themselves if they think they can provide a vocabulary for discourse about unity and wholeness which does not perpetuate social domination of individuals, given how much language is saturated and pathologically infected by ideology.

The Adornian could accept my concerns about the structure of the dialectic between Hegelian and critical theorist, and could even go so far as to concede it is possible, though unlikely, to have commitments to unity, etc., whose vocabulary does not aim to establish or bring about social domination. However, where Hegelian metaphysics and social philosophy go wrong is in claiming that rationality can only be realised in the whole, namely the state: both the Hegelian and the critical theorist agree that "[n]either freedom nor self-realising reason is absolute, independent from others, but they depend for their realisation on other social concepts and on real, physical human beings". ${ }^{59}$ However, for all of their convergence on a radically anti-Cartesian conception of autonomy and subjectivity, the critical theorist will invariably express serious reservations about realising autonomy qua the capitalist state, where such a state is typified by social stratification and the various forms of alienation resulting from the ideological appropriation of exchange and labour.

In response, the Hegelian could claim that the state which actualises autonomy is not in fact the neoliberal capitalist socio-economic system, since such a system does not in fact embody the level of rationality required for the rational state: from a social democratic Hegelian perspective, the framework of neoliberal capitalism hinders the growth of individual freedom and places barriers on the development of autonomy, since the kind of practices the capitalist framework encourages are practices which are not rational practices.

${ }^{59}$ Ibid., p. 90. 
In order to effect the realisation of rationality in Objective Spirit, one would need to sublate the current socio-economic paradigm, where such sublation involves the project of reconciliation. Central to this project is the idea of celebrating difference and individuality, where the logic of reconciliation is designed to prohibit any form of repression of subjectivities. For example, under social democracy, one conceives of individuals as selfdetermining agents, as opposed to reified capitalist instruments. In this sense, there is a clear development in recognitive practices, since individuals "count as more than just equal bearers of labour power performing one simple function in the system" ${ }^{60}$ Hegelian social theory, therefore, is anything but committed to maintaining an oppressive status quo, since dialectically transitioning from immediate unity to mediated unity necessarily requires significant respect for difference. As Neuhouser writes, “[i]mplicit in Hegel's view of ethical life's Conceptual structure is the claim that part of what makes the modern social world rational is that it allows its members to develop and express different, complementary identities. The idea here is that each type of identity has a distinct value for individuals and that possessing them all is essential to realising the full range of possible modes of selfhood. To miss out on any of these forms of social membership, then, is to be deprived of one of the basic ways of being a self and hence to suffer an impoverishment of one's life". ${ }^{61}$ But if the Adornian is still convinced that interdependency between individual and a progressive state is still a form of oppression, then I worry that not only would they would be relapsing into the fallacious way of thinking exposed by both Hegel and Dewey, they would also risk returning to the very model of individuality Adorno and the critical theorists abhor: the Hobbesian model of the individual as atomistic, totally egoistic and asocial. ${ }^{62}$

I take the arguments proposed in this paper to hopefully go to some considerable length in clearing Hegel of the charge levelled at him by Adorno: even though I have contended that Hegel's dialectical treatment of the categories of universality and individuality should not be interpreted as evidencing a lack of interest in or even disdain for individuals, there is an important lesson to be learned from drawing attention to potentially fatal ambiguities that are ripe for perversion and exploitation by authoritarian ideologies. Ironically, then, it would appear that a staunch defence of Hegel against misunderstandings of his views is exactly the kind of argumentative approach a critical theorist ought to perform.

\footnotetext{
${ }^{60}$ Ibid., p. 82.

${ }^{61}$ Neuhouser, 2008: 223.

62 Such a conception of individuality would also involve conceiving of moral subjectivity as being abstract/empty/formal. Cf. PR: $§ \S 134-7,141$.
} 


\section{References}

Adorno, T. W. 1981. Negative Dialectics. E. B. Ashton (trans.) and (ed.) London: Continuum --- 1997. Aesthetic Theory. G. Adorno and R. Tiedemann (eds.) R. Hullot-Kentor (trans.) London: Athlone Press.

--- 2000. Metaphysics: Concepts and Problems. R. Tiedemann (ed.) and E. Jephcott (trans.) Cambridge: Polity Press.

Baumann, C. 2011. 'Adorno, Hegel and the Concrete Universal'. Philosophy and Social Criticism 37: 73-94.

Beiser, F. C. 2005. Hegel. New York \& London: Routledge.

--- 2014. After Hegel: German Philosophy 1840-1900: Princeton, NJ: Princeton University Press.

Black, M. 1952. 'The Identity of Indiscernibles'. Mind 61: 153-164.

Dewey, J. 1981-1990. The Later Works, 17 volumes, J. Boydston (ed.) Carbondale: Southern Illinois University Press (abbreviated here as LW, followed by volume number).

Dulckeit, K. 1986. 'Can Hegel Refer to Particulars?'. The Owl of Minerva 17: 181-194.

Feuerbach, L. 1972. The Fiery Brook: Selected Writings of Ludwig Feuerbach. Z. Hanfi (trans.) Garden City: Doubleday.

Finlayson, J. G. 2014. 'Hegel, Adorno and the Origins of Immanent Criticism'. British Journal for the History of Philosophy 22: 1142-1166.

Forster, P. 2011. Peirce and the Threat of Nominalism. Cambridge: Cambridge University Press.

Hardimon, M. O. 1994. Hegel's Social Philosophy: The Project of Reconciliation. Cambridge: Cambridge University Press.

Hegel, G. W. F. 1969. Science of Logic. A. V. Miller (trans.) London: Allen and Unwin.

--- 1975. Lectures on the Philosophy of World History. H. B. Nisbet (trans.) Cambridge: Cambridge University Press.

--- 1977a. Phenomenology of Spirit. A. V. Miller (trans.) Oxford: Oxford University Press.

--- 1977b. The Difference between Fichte's and Schelling's System of Philosophy. H. S. Harris \& W. Cerf (trans.) Albany, NY: State University of New York Press.

--- 1991a. The Encyclopaedia Logic. T. F. Geraets, W. A. Suchting, and H. S. Harris (trans.) Indianapolis/Cambridge: Hackett Publishing Company, Inc. 
--- 1991b. Elements of the Philosophy of Right. A. W. Wood (ed.) H. B. Nisbet (trans.) Cambridge: Cambridge University Press.

--- 1995. Lectures on the History of Philosophy. E. S. Haldane (trans.) Lincoln, NA: University of Nebraska Press.

Houlgate, S. 2006. The Opening of Hegel's Logic: From Being to Infinity. West Lafayette, IA: Purdue University Press.

--- forthcoming. 'Is Hegel's Phenomenology of Spirit an Essay in Transcendental Argument?', in S. Gardner (ed.) The Transcendental Turn. Oxford: Oxford University Press. Hume, D. 1978. A Treatise of Human Nature. L. A. Selby-Bigge (ed.) and P. H. Nidditch (rev.) Oxford: Oxford University Press.

Locke, J. 1975. An Essay concerning Human Understanding. P. H. Nidditch (ed.) Oxford: Oxford University Press.

Loux, M. J. 1978. Substance and Attribute. Dordrecht: Riedel.

--- 1998. 'Beyond Substrata and Bundles: A Prolegomenon to a Substance Ontology', in S. Laurence \& C. Macdonald (eds.) Contemporary Readings in the Foundation of Metaphysics. Oxford: Blackwell.

Lowe, E. J. 1989. Kinds of Being: A Study of Individuation, Identity and the Logic of Sortal Terms. Oxford: Blackwell.

--- 1999. 'Form without Matter', in D. S. Oderberg (ed.) Form and Matter: Themes in Contemporary Metaphysics. Oxford: Blackwell.

Melamed, Y. Y. 2010. 'Acosmism or Weak Individuals? Hegel, Spinoza, and the Reality of the Finite'. Journal of the History of Philosophy 48: 77-92.

--- 2012. 'Why Spinoza is not an Eleatic Monist. Or Why Diversity Exists?', in P. Goff (ed.) Spinoza on Monism. Basingstoke: Palgrave Macmillan.

Moore, A. W. 2012. The Evolution of Modern Metaphysics: Making Sense of Things. Cambridge: Cambridge University Press.

Newlands, S. 2011. 'Hegel's Idealist Reading of Spinoza'. Philosophy Compass 6: 100-8.

Neuhouser, F. 2000. Foundations of Hegel's Social Theory: Actualising Freedom. Cambridge, MA: Harvard University Press.

--- 2008. 'Hegel's Social Philosophy', in F. C. Beiser (ed.) The Cambridge Companion to Hegel and Nineteenth Century Philosophy. Cambridge: Cambridge University Press.

Patten, A. 1999. Hegel's Idea of Freedom. Oxford: Oxford University Press. 
Pinkard, T. 1994. Hegel's Phenomenology: The Sociality of Reason. Cambridge: Cambridge University Press.

Pippin, R. B. 1989. Hegel's Idealism: The Satisfactions of Self-Consciousness. Cambridge: Cambridge University Press.

Pringle-Pattison, A. S. 1897. Man's Place in the Cosmos. Edinburgh: William Blackwood.

Schelling, F. W. J. 1974-6. Sämmtliche Werke. 14 vols. K. F. A. Schelling. Darmstadt: Wissenschaftliche Buchgesellschaft.

Stern, R. 2007. 'Hegel, British Idealism, and the Curious Case of the Concrete Universal'. British Journal for the History of Philosophy 15: 115-153.

--- 2009. Hegelian Metaphysics. Oxford: Oxford University Press.

--- forthcoming. 'Determination is Negation: The Adventures of a Doctrine from Spinoza to Hegel to the British Idealists'.

Taylor, C. 1972. 'The Opening Arguments of the Phenomenology', in A. MacIntyre (ed.) Hegel: A Collection of Critical Essays. Notre Dame: Notre Dame University Press.

--- 1987. 'Overcoming Epistemology', in K. Baynes, J. Bonham and T. McCarthy (eds.) After Philosophy: End or Transformation?. Cambridge, MA: MIT Press.

Westphal, M. 1993. 'Hegel's Theory of the Concept', in L. Stepelevich (ed.) G. W. F. Hegel: Selected Writings. Atlantic Highlands: Humanities Press International.

Zimmerman, D. W. 1997. 'Distinct Indiscernibles and the Bundle Theory'. Mind 106: 305-9. 